Thematic review

\title{
Plant Use in the Mesolithic Period. Archaeobotanical Data from the Czech Republic in a European Context - a Review
}

\author{
Michaela Divišováa*, Petr Š́da a,b \\ ${ }^{a}$ Laboratory of Archaeobotany and Palaeoecology, Faculty of Science, University of South Bohemia in České Budějovice, Branišovská 31, \\ 37005 České Budějovice, Czech Republic \\ ${ }^{b}$ Department of Archaeology, University of West Bohemia, Faculty of Arts, University of West Bohemia in Plzeñ, Sedláčkova 15, 30614 Plzeň, Czech Republic
}

\section{ARTICLE INFO}

\section{Article history:}

Received: $29^{\text {th }}$ December 2014

Accepted: $1^{\text {st }}$ August 2015

\section{Keywords:}

hunter-gatherers

archaeobotany

Mesolithic

plant use

Czech Republic

\section{$A B S T R A C T$}

The present work attempts to provide an understanding of the issue of Mesolithic archaeobotany, especially in terms of plant use, woodland clearance, and a discussion concerning Mesolithic agriculture. Plant use patterns in hunter-gatherers are also presented and discussed. Special attention is paid to taxa occurring within archaeological context at Mesolithic sites in Europe, particularly in the Czech Republic, along with ethnobotanical evidence for their use.

\section{An outline of the history of research into hunter- gatherer archaeobotany with an emphasis on the European Mesolithic}

The importance of plants in the diet of the modern huntergatherer has already been stressed by Lee (1968) on the basis of data from the Ethnographic atlas (Murdock 1967). However, archaeologically, most studies dealing with foods have long put an emphasis on animal remains - bones - most likely due to their visibility in the archaeological record and also to the research methods applied. Moreover, when dealing with plants, investigations of domesticated and cultivated plants (or their immediate wild relatives) have long prevailed in archaeobotanical studies (Hather, Mason eds. 2002). As a result, the role of plants has been systematically underestimated (Zvelebil 1994; Hather, Mason eds. 2002).

*Corresponding author. E-mail: MDivisova@seznam.cz
From a European perspective a crucial turning point occurred in 1994, when M. Zvelebil published a key study concerning the use of plants in the Mesolithic. In this study, he built on Clarke's model (1976), in which Clarke emphasizes the wide availability of potential plant foods in temperate and Mediterranean Europe. Zvelebil (1994), however, reviewed the temporal evidence and brought together information on finds of edible plant remains from 74 northern European sites. He revealed that at 40 sites only the remains of Corylus sp. were reported; additionally, 24 sites had only two species, commonly Corylus sp. and Quercus sp. or Trapa natans. Taxa such as Prunus sp., Chenopodium sp., Nuphar lutea, Nymphaea alba, Rubus idaeus, Polygonum sp., Crataegus sp., Rumex sp., Filipendula sp. Malus sp., or Pyrus sp. had also been occasionally reported. Apart from plant macroremains, Zvelebil also discussed other lines of evidence of plant use, such as pollen data, artefactual, and palaeopathological evidence. He concluded that, based on these four lines of evidence, patterns of plant use in the Mesolithic should be considered in terms of wild plant food 
husbandry instead of the incidental and opportunistic use of plants for food.

Since then, rather individual reports by a few authors instead of a systematic study of the issue can be observed (e.g. Holden et al. 1995; Regnell et al. 1995; Kubiak-Martens 1996; 1999; Knörzer et al. 1999; Perry 1999; Mason, Hather 2000; Robinson 2000; Rösch 2000). An exception is the edited volume Hunter-gatherer archaeobotany. Perspectives from the northern temperate zone (Hather, Mason eds. 2002), which represents a significant milestone in huntergatherer archaeobotany. Within this volume, a number of investigations of European sites were undertaken (e.g. Mason et al. 2002; Perry 2002; Robinson, Harild 2002; Zapata et al. 2002). Several tentative conclusions were drawn from this project. Firstly, the number of small seeds and fruits recovered is extremely low, which can be assigned to poor preservation, implying that focusing only on fruits and seeds may not be sufficient when dealing with pre-agricultural societies. Secondly, most importantly, the identification of parenchyma turns out to be of crucial importance when studying past hunter-gatherers, since underground storage organs such as rhizomes, roots, and tubers are expected to play an important role in relation to seeds and fruits and, furthermore, are frequently present at investigated sites. However, the identification of parenchymatous tissues is fraught with many practical problems, particularly the need to examine the remains by scanning electron microscopy (SEM). Further, larger seeds and fruits such as Corylus sp., Trapa natans, Quercus sp., Prunus sp. or Crataegus sp. are often present and identified. With respect to methodology, a need for a holistic approach, incorporating various disciplines such as experimental archaeology, ethnobotany, and also broader archaeobotanical analyses, including anthracology and palynology, are stressed (Mason et al. 2002). Also, proper sampling and recovery techniques should be applied to obtain satisfactory reflection on the issue. The authors further noted that the application of such an holistic approach is relatively time-consuming and its time-effectiveness often questionable, which may also be reflected in the state of the research.

Since then, several works presenting new data deserve to be mentioned here (Kubiak-Martens 2002; Aura et al. 2005; Out 2008a). However, another work well worth considering in the history of research into hunter-gatherer archaeobotany is the dissertation of W. Out, Sowing the seed? Human impact and plant subsistence in Dutch wetlands during the Late Mesolithic and Early and Middle Neolithic (5500-3400 cal BC); this brought substantial evidence on natural vegetation, human impact, plant use and cultivation processes in the Dutch wetlands during the Mesolithic and Neolithic, hence, contributing to an understanding of the transition from hunting and gathering to agriculture on the basis of archaeobotanical research (Out 2009). In terms of further research development, some studies concerning archaeobotany at European Mesolithic sites should be mentioned (Filipović et al. 2010; Holst 2010; Regnell 2011; Out 2012; Bishop et al. 2013; 2015; Deforce et al. 2013; Marinova et al. 2013; Out, Verhoeven 2014).
Another point to be made is that, apart from being food items, the evidence for the wider human use of plants, such as for structures and as artefacts, should be emphasised. Such uses include for housing and thatching, as vessels and objects of art, sources of fibres for cordage and textiles, dyeing, tanning, and medicinal and psychoactive agents, etc. (Hather, Mason 2002). This issue has been tackled by a number of authors such as Burov (1998), Hurcombe (2000; 2007), Mason et al. (2002), Zapata et al. (2002), Hardy (2007; 2008), and Wood (2011) from the perspective of ethnographic, archaeobotanical, and experimental evidence.

To summarize, according to above-mentioned studies, several patterns can be observed. Firstly, plant macroremains bring substantial evidence about only a few intentionally-used species. Secondly, a clear pattern arises concerning hazelnuts as the most important plant food resource (e.g. Holst 2010; Regnell 2011); however, their role may be overestimated, particularly in relation to other resources such as roots and tubers (Mason et al. 2002). This relates to another important issue concerning foods such as roots, inner bark, stems, leaves, or other vegetative parts of plants; their presence in the assemblage suggests they were available. However, there is a need to identify them and integrate the results from all categories of evidence, since a number of studies have proved that these remains may be identified by scanning electron microscopy (e.g. Hather 1991; 1993; 2000; Holden et al. 1995; Kubiak-Martens 1996; 1999; 2002; 2008; Perry 1999). Therefore, a modification of the methodological practices common on agrarian sites is needed. Lastly, it should be noted that most of the published information on plant use in the Mesolithic lacks critical evaluation, since the presence of taxa cannot be uncritically associated with their utilisation.

\section{Plant use patterns in hunter-gatherers}

Another issue deserving attention is the intensity of plant use in the Mesolithic. As already mentioned, the great scarcity of archaeobotanical data makes it difficult to estimate the contribution of plants to the Mesolithic diet. The extent and significance of Mesolithic plant use has been suggested to vary between $5 \%$ and $80 \%$, with $15-20 \%$ being the most commonly proposed estimate by several scholars (e.g. Clarke 1976; Jochim 1976; Price 1978; see Zvelebil 1994 for further details). These represent very approximate estimations and considerable variation, likely in the case of individual European regions, should be taken into account, as also the dependence on the availability of fatty aquatic resources, fat content of terrestrial mammals, birds, fish, and the overall seasonality. Added to the above, it is important to bear in mind that the human intolerance of a lean-meatbased diet indicates that at least $50 \%$ of human energy needs had to come from fat or plant foods (Speth et al. 1991), since lean meat can compose no more than $35 \%$ of dietary energy (Hardy 2010). When focusing on central European inland Mesolithic communities with rare or no fatty aquatic 
resources, the contribution of plants in satisfying human energy needs and protein requirements varying between $30 \%$ and $40 \%$ has been proposed, depending on the fat content of the available terrestrial mammals, game birds, and fish (Zvelebil 1994, 58).

Moreover, these data can be compared with ethnographic accounts, since the diets of modern-day hunter-gatherers may represent a reference to past pre-agricultural dietary practices. Subsistence data on a worldwide hunter-gatherer diet based on an ethnographic atlas (Gray 1999) have been analysed and the following trends have been recognised (Cordain et al. 2000). The authors reported that, when it was ecologically possible, hunter-gatherers gained between $45-65 \%$ of energy from animal foods. Most (73\%) huntergatherer societies derived between $56 \%$ and $65 \%$ of their subsistence from animal foods, whereas $14 \%$ of these communities consumed more than $50 \%$ of wild plant foods (Cordain et al. 2000). Another noticeable fact, considering the ethnographic evidence, is the diversity within known hunter-gatherer diets. According to Kelly's ethnographic atlas (1995), diets whose gathered component (including small mammals and fish) varies from $0 \%$ to $85 \%$, include a hunted portion varying from $10 \%$ to $90 \%$ and a fish element from $0 \%$ to $80 \%$.

Taken together, these observations suggest that the plant component in the hunter-gatherer diet is not negligible. On the other hand, one should be cautious, since, as already mentioned above, food resources vary by latitude, environment, and season. Thus, one must guard against overgeneralization and drawing precise analogies between modern-day and Mesolithic hunter-gatherer, particularly due to the fact that the diets of many modern huntergatherer communities contain substantial portions of domesticated resources having different concentrations of fats, carbohydrates, vitamins, fibre, minerals, etc. (Jenike 2001, 208).

In addition, the ethnographic record also indicates that not all available resources were utilised. This is clearly apparent in the example of the Kalahari !Kung, who consider 85 plant species edible; however, more than half of the entire plant diet is formed by a single plant species, the mongongo (Schinziophyton rautanenii) (Lee 1968; 1973). Also, other factors affecting food choice should be taken into consideration. Apart from availability mentioned above, one should bear in mind that social factors, fashion, affluence, price, religion, tradition, cultural patterns, etc., could all have played an important role in food choice (Fisher, Bender 1970, 6-7).

Furthermore, ethnographic accounts have repeatedly shown the wide range of behaviour and the flexibility of hunter-gatherers. Hunter-gatherer diversity in habitat, technology, diet, physical attributes, reproductive histories, technology, languages, social organisation, issues of local response to environmental constraints, etc., has been well reported among present and past hunter-gatherers (PanterBrick et al. 2001). Thus the danger of misinterpretation and overgeneralization must be emphasised.
To summarize, current finds need to be critically reevaluated since many of them lack information concerning their particular archaeological context - and the presence of potential useful plants at the site itself cannot be considered as convincing evidence for their utilisation. Unfortunately, this is often disregarded in publications dealing with huntergatherer archaeobotany. Evidence of food plants can then be provided by plant remains found in human intestines or human coprolites. Strong indication for plant foods may be represented, for instance, by plant residues in storage pits or vessels, which are regrettably exceptional in the Mesolithic context. On the other hand, criteria to prove human transport and manipulation of plants suggested by Dietsch (1996) should be taken into consideration. According to Dietsch (1996), the following five main criteria may be observed to enable the detection of wild plants manipulated by humans:

1. Ecology, which can be used to identify the presence of taxa outside their natural environment.

2. Number of plant remains, since overrepresentation of some taxa may reflect gathering.

3. Carbonization, which may indicate human processing activities.

4. Fragmentation, also suggesting possible plant processing practices.

5. Spatial distribution, as location in archaeological structures may reflect anthropogenic manipulation.

\section{Human impact on the vegetation: woodland clearance}

Apart from the evidence available from plant macroremains, pollen studies play an important role in understanding the human impact on vegetation in the Mesolithic. During this period, hunter-gatherers started to be less mobile due to environmental changes and consequently affected their local environments around camp sites more intensively (Kuneš et al. 2008). In particular, the phenomenon of woodland clearance belongs to one of the most discussed issues concerning Mesolithic societies.

Although, traditionally, Mesolithic communities were not expected to clear forests (see Vera 2000), these disturbance phases visible in pollen diagrams, for example, in Britain (e.g. Simmons 1996; Innes et al. 2003), Germany (Bos, Urz 2003), and recently also the Czech Republic (Nováková et al. 2008; Pokorný et al. 2008; 2010), are associated with evidence of regular and recurrent burning and clearance activity delaying forest regeneration (Jacobi et al. 1976; Mellars 1976). Such burning of the vegetation is documented not only by the permanent presence of microcharcoal in pollen records, but also the increased incidence of certain anthropogenic pollen indicators. These are plants that prefer open habitats, such as Thalictrum, Rumex, Melampyrum, Plantago lanceolata, Poaceae, and those that expand to fire-affected areas, including Pteridium aquilinum, or Calluna vulgaris (Simmons 1996; Pokorný 1999; Kuneš et al. 2008; Pokorný et al. 2008).

Such evidence also supports the suggestion that Mesolithic people deliberately manipulated their environment as a part 
of an organized land-use strategy (Zvelebil 1994). However, these disturbances can also be interpreted in terms of natural processes such as lightning strikes, storms, windthrows, etc., that would leave an identical signal in the palaeoecological record to that of anthropogenic clearance (Simmons 1996; Brown 1997). In addition to that already mentioned, it has been proposed that only the presence of cereal pollen can indicate without doubt the anthropogenic origins of disturbances (Simmons, Innes 1987), but this would consider only forest clearances associated with cereal cultivation (Zvelebil 1994). Despite all of this, Mesolithic sites are almost everywhere in the world accompanied by large amounts of microcharcoal, which is found in sedimentary records. This plays into the idea of burning forests as the usual way of dealing with nature (Sádlo et al. 2008) and a continuous presence of microscopic charcoal in sediments is now also considered as a reliable indicator of human activity during the pre-agricultural Holocene (Pokorný 1999).

Moreover, it is generally accepted that woodland clearances, irrespective of their causation, were utilized by Mesolithic populations for food procurement. However the clearances were created, they had an economic use. Plant and animal productivity could be almost doubled by a strategy of controlled burning (Mellars 1976). Forest clearance would have led to particular advantages for the propagation of edible plants and clearings also serve to facilitate hunting as well as the mobility of human populations (Jacobi et al. 1976; Mellars 1976; Zvelebil 1994; Mason 2000).

One should also take into account the fact that discussion concerning Mesolithic societies is seriously lacking (Davies et al. 2005). However, ecological relationships may have been a key factor in the development of social relationships in the Mesolithic and it is important not to separate the economic from the cultural, particularly in terms of understanding human interaction with woodlands in the Mesolithic (Moore 2003). Nonetheless, environment and the trees within it should be considered as more than mere background to human activity. In this regard, it is important to distinguish between two possible modes of human-environment relationships. The first can be described as a beneficent human-environment relationship, where human and non-humans influence one another in a mutually beneficial way. This is in contrast, however, to another mode of human-environment relationship, a concept of wilderness where fear is a primary motivator determining behaviour and the surroundings are more often seen as malevolent rather than benevolent (Evans et al. 1999; Warren 2003; Davies et al. 2005).

With respect to anthropological and ethnographic evidence, Davies et al. (2005) suggest that Mesolithic populations may have more likely been driven by anxiety and fear of their surroundings, rather than be familiar with it. Thus, considering woodlands as being marked by paths (Tilley 1994, 202; Warren 2003), one of the primary motivators in establishing paths may have been a fear of actual harm from wildlife, or spirits, or of getting lost in surroundings where the horizon is seldom visible. Consequently, woodland clearings could have resulted from such fears and can be explained as a purely social phenomenon.

\section{Mesolithic agriculture?}

There has also been a discussion of the accumulating archaeobotanical evidence pointing to agricultural activity being in central and northern Europe well before the onset of the Neolithic (Innes et al. 2003; Klassen 2004; Poska, Saarse 2006; Behre 2007; Tinner et al. 2007). The palynological evidence is based on the consistent presence of Cerealia pollen within sediments that provide high temporal resolution and precision for the period of interest. The presence of pollen of Cerealia during the Mesolithic period also correlates with the pollen of semi-cultural plants or weeds, such as Plantago lanceolata that is considered to be one of the most reliable indicators of agriculture (Tinner et al. 2007; see Behre 2007 for further discussion). Given that the evidence for cereal cultivation during the Mesolithic is provided, for instance, from Switzerland, Austria, France, Estonia, British Isles (Innes et al. 2003; Poska, Saarse 2006; Tinner et al. 2007), etc., some scholars (e.g. Tinner et al. 2007) consider the occurrence of pollen indicative of agriculture activities during the Late Mesolithic as a widespread phenomenon in Europe.

However, the topic remains at the centre of controversial debate mainly because there are no well-dated macroremains of crop plants of pre-Neolithic age (Behre 2007); this may be due to there being no Upper Mesolithic sites in and around central Europe known, which have good conditions for the preservation of botanical remains (Jacomet, Kreuz 1999). Mesolithic agriculture, as it is assumed, is based solely on the occurrence of single Cerealia or Cereal-type pollen in the respective levels of pollen diagrams (Behre 2007; Tinner $e$ al. 2007). Firstly, single pollen grains of Cerealia-type which have been interpreted as indicators of earliest agriculture, however, may not really derive from cereals, because cereal pollen can be morphologically similar to that of wild grasses and is not always distinguishable (Dumayne-Peaty 2001, 381). Another issue is the spontaneous polyploidization of wild grasses, which leads to the development of large pollen grains, contributing to the difficulties of identifying cereals (Behre 2007; Pokorný et al. 2008). In addition to misidentification, there are also problems of contamination or the possible long-distance transport of Cereal-type wild grass pollen grains from the Near East and the eastern Mediterranean that cannot be distinguished from cereals (Behre 2007). Another explanation of the appearance of pre-Neolithic cereal-type pollen would be the cultivation of indigenous wild grasses (Zvelebil 1994).

One of the most common arguments for ruling out Mesolithic agriculture is that crops cannot be produced without permanent settlement activity protecting the fields against herbivores (Behre 2007). However, protection can be provided by simple fence constructions made from prickly shrubs (Pokorný, Sádlo 2008). Moreover, the evidence 
suggests that possible cereal production during the Mesolithic was of low-intensity and the purpose for this could have been the planting of cereals for prestige reasons (Mithen 1996; Tinner et al. 2007). Although this may represent an economically-useful activity, one should take into account that growing sedentarism, associated with the adoption of agriculture, gave rise to epidemics and health problems and should not be perceived unambiguously (Tringham 2000; Bánffy 2005; Beneš 2013). On the other hand, very little is known about the social organisation and beliefs of Mesolithic communities in central Europe, particularly in contrast to the south-east European Neolithic and the issue concerning the origins of agriculture, where the cult and ritual life has been well documented in the archaeological record (Hodder 1990; Bánffy 2005).

\section{Selected plants occurring in the Mesolithic context: perspectives from archaeobotany and ethnobotany}

The plant macroremains of the following taxa are recorded as occurring at European Mesolithic sites based on the above-mentioned studies. Special attention is also paid to taxa recovered from sites in the Czech Republic. Here, ethnobotanical information on these plants is also provided. It should be kept in mind that these are not all the taxa identified within the Mesolithic context, but rather those taxa that occur at several sites or within a context suggesting their manipulation by humans are presented and discussed.

\subsection{Seeds, fruits and nuts \\ 5.1.1 Corylus avellana}

Hazelnut shells represent very abundant macroremains at most sites. Very likely, hazelnuts functioned as staple food, since their energetic value is very high, containing more than $60 \%$ fat, $15 \%$ protein and nearly $17 \%$ carbohydrate, in addition to a large amount of unsaturated fatty acids, minerals and vitamins (Holst 2010). However, they are easily recognisable in contrast to other sources, particularly underground storage organs in the archaeological record; their role, therefore, may be overestimated (Mason et al. 2002). Their frequent occurrence may also be connected with their roasting, which facilitates hazelnut cracking and grinding, destroys contaminants, induces a nutty flavour and digestion and, last but not least, enables their synchronous harvest (Mithen et al. 2001; Mears, Hillman 2007; Holst 2010).

Large amounts of hazelnut shells are known, for instance, from the sites of Duvensee, Germany (Holst 2010) or Staosnaig, Scotland (Mithen et al. 2001). In the Czech Republic, finds of hazelnut shells are reported from Okrouhlík, Dolský Mlýn, Máselník, Pod Zubem, Pod Krrídlem, Arba, Sojčí Převis, Jezevčí Převis, Kristova Jeskyně, Schwarzenberg Lake, Údolí Samoty, Dvojitá Brána u Rohlin, (Opravil 2003; Pokorný 2003; Komárková 2005; Pokorný et al. 2008; Žáčková 2008; Svoboda et al. 2013; Divišová 2014).

\subsubsection{Quercus sp.}

Acorns are nutritionally comparable to cereals, being largely a source of carbohydrates, fats and fibres. Acorn also contains proteins, amino acids and vitamins, mostly $\mathrm{A}$ and C. Apart from acorns for food, oaks were exploited for numerous other purposes, including construction material, charcoal production, firewood, production of rope, and the extraction of tannin (Rosenberg 2008, 169).

With respect to the Mesolithic period, S. L. R. Mason (2000) considered the possible role played by fire and challenged the traditional view that fire might have been used mainly to improve hunting (Mason 2000, 139-140). Instead, she focuses on the manner in which burning contributes to acorn gathering and posits that burning reduces competition for nutrients, etc., from other species, and in so doing concentrates available resources to the acorn crop. In addition, removing ground cover facilitates the gathering of acorns.

Finds of acorns are reported from a number of sites such as Tybind Vig and Halsskov, Denmark (Kubiak-Martens 1999; Robinson, Harild 2002) or Roc del Migdia, Catalonia (Holden et al. 1995).

\subsubsection{Trapa natans}

Fruits of Trapa natans are rich in starch (50\%), protein (10\%) and fat. They can be eaten raw, as well as boiled or roasted. They can also be preserved for several weeks, when roasted. As in the case of hazelnuts, roasting makes them easier to open, ground to flour and a better flavour is also induced (Renfrew 1973; Karg 2006). Remains of T. natans have been found, for instance, at sites in the Dutch central river area (Out 2009). In the Czech Republic, fruits of T. natans have been found at the site of Schwarzenberg Lake (Pokorný et al. 2008; 2010).

\subsubsection{Cornus mas}

Bushes of Cornus mas bear edible fruits, which are widely used as food and medicine, since they contain a large amount of vitamin C (Klimenko 2004; Łuczaj 2012). Interestingly, finds of C. mas stones in deposits related to burial infill are reported from the site of Vlasac, Serbia (Filipović et al. 2010).

\subsubsection{Cornus sanguinea}

Although the edibility of fruits of $C$. sanguinea is discussed (Dietsch 1996; Out 2009), they are known to be eaten from the ethnobotanical record (e.g. Dénes et al. 2012). The fruits are slightly toxic, but their palatability and edibility increase after preparation. Moreover, selective use of $C$. sanguinea for Mesolithic and Neolithic fish traps has been observed in the Netherlands (Out 2008b). There are finds of stones of $C$. sanbuinea at several sites in the Netherlands (Out 2009) as well as in Denmark (Kubiak-Martens 1999).

\subsubsection{Rubus sp.}

Fruits of Rubus taxa represent a food resource often referred to as unsuitable for storage (Out 2009). On the 
other hand, recent hunter-gatherers have been reported to store them over the winter (Mears, Hillman 2007). Also, these taxa may be consumed directly without any preparation and evidence of their consumption may thus be underrepresented (Out 2009). Ethnobotanically, the utilization of Rubus fruits, leaves, roots, as well as whole plants, mostly for food and medicine, may be traced (Moerman 1998, 492-494; Mears, Hillman 2007). Fruits or Rubus taxa have been found at several sites, for example, $R$. idaeus from the site of Halsskov, Denmark can be mentioned (Robinson, Harild 2002). In the Czech Republic, $R$. idaeus and $R$. saxatilis have been retrieved from Jezevčí převis and Schwarzenberg lake (Pokorný 2003; Žáčková 2008; Pokorný et al. 2010).

\subsubsection{Sambucus sp.}

Sambucus nigra represents one of the most versatile plants used for food, medicine, crafts and games, as well as for ornamental purposes. In addition, almost every part of the plant, including the bark, roots, leaves, flowers, and fruit, has some uses. Finds of Sambucus ebulus/nigra are known, for instance, from Vlasac, Serbia (Filipović et al. 2010). In the Czech Republic, seeds of Sambucus nigra were recovered from Jezevčí převis (Pokorný 2003).

In contrast to Sambucus nigra, S. racemosa requires processing to render it edible, since the fruit and its seeds are somewhat toxic. However, S. racemosa represents a widelyused food, as well documented through the ethnobotanical record, representing a particularly good source of vitamin $\mathrm{C}$, copper and fibre. Due to its toxicity, the berries are nearly always described as being cooked prior to consumption. Native American groups on the southern Northwest Coast cooked red elderberry fruit through steaming on rocks, pitbaking, and boiling. Interestingly, there are no clear reports that seeds were removed during the cooking or drying phases of processing. Seeds were generally removed while the fruit was being consumed. Red elderberry appears to have been a readily and commonly stored fruit on the Northwest Coast, also being described as an important winter food (Moerman 1998, 513-514; Losey et al. 2003). In the Czech Republic, Sambucus racemosa was recorded at the site of Dvojitá brána u Rohlin (Divišová 2014).

\subsubsection{Chenopodium album}

Chenopodium album has edible foliage as well as easily gatherable seeds, which can be harvested in great quantity. Its extensive use for food as well as medicine is widely known. The green leaves and stems are eaten raw, boiled or dried for future use. The seeds are most commonly used for porridge or ground into flour, subsequently used for making bread (e.g. Moerman 1998, 154-155; Mears, Hillman 2007). Seeds of C. album are commonly found at Mesolithic sites. For example, Halsskov and Tybrind Vig, Denmark (Kubiak-Martens 1999; Robinson, Harild 2002) or German Rhineland (Knörzer et al. 1999) can be mentioned. In the Czech Republic, the presence C. album has been recorded at Jezevčí převis (Pokorný 2003).

\subsubsection{Rosa sp.}

The fruits of Rosa sp. are edible, characterized by a uniquely high concentration of vitamin $\mathrm{C}$. On the other hand, it is interesting to note that although the flesh is of good taste, the seeds and hairs need to be rinsed away as they cause choking and irritation of the throat (Mears, Hillman 2007). Fruits of Rosa sp. have been found for instance at the Danish site of Tybrind Vig (Kubiak-Martens 1999) or at Dutch wetland sites (Out 2009).

\subsubsection{Malus sylvestris}

Malus sylvestris bears good tasting fruits, although their vitamin content is relatively poor. However, the energetic value of dried apples is considerable, since they contain $62 \%$ carbohydrate (Renfrew 1973; Out 2009). Fruit fragments and seeds of $M$. sylvestris have been recovered from several sites, e.g. Tybrind Vig, Denmark (Kubiak-Martens 1999).

\subsection{Green vegetables}

Many taxa found at Mesolithic sites represent plants which could have been used as green vegetables, although one should bear in mind that this is extremely difficult to prove. Among these potentially edible taxa, namely Chenopodium album (see above), Urtica dioica, Phragmites australis, Rumex crispus, Rumex sp., Atriplex sp., Stellaria media, Polygonum sp., Potentilla anserine, etc., can be considered.

\subsection{Roots/tubers/rhizomes}

As already mentioned, underground storage organs are argued to represent an important food resource in European Mesolithic. Furthermore, many of the following plants are known for their extremely versatile use. A case study concerning the use of Pteridium aquilinum is presented below to illustrate this phenomenon. Not only Pteridium aquilinum, but also taxa such as Ficaria verna, Bolboschoenus maritimus, Beta vulgaris ssp. maritimus, Typha latifolial angustifolia, Allium sp., Sagittaria sagittifolia, Polygonum sp., Phragmites australis, Schoenoplectus lacustris, Nymphaea alba, Nuphar lutea etc. should be perceived in this manner.

\subsubsection{Pteridium aquilinum}

The bracken has been widely utilized in a variety of ways by humans in all parts of the world (Rymer 1976). Bracken has been mainly used as a food. Either the young fronds ('fiddleheads') or the rhizomes have been widely used as food in many areas such as aboriginal Australia, New Zealand, North America, Britain or Japan. The rhizomes in particular have considerable stores of starch and have been the source for a sort of flour, which was used as a caloric staple by hunter-gatherers such as the Maori of New Zealand (McGlone et al. 2005) and the indigenous people of Western Washington (Norton 1979). The ethnographic record even shows how this fern was collected and prepared as a form of flour and baked or dried into cakes and bread.

The ethnographic record also shows that plant management by burning was occurring in Western Washington in association 
with bracken, which survives periodic burning well since its top growth dies down in the autumn and the root system is not harmed by fires. Moreover, not only does land management by burning encourage bracken growth, but heating bracken can also reduce its toxicity (Pohl 1955, Norton 1979).

Apart from the already-mentioned use of bracken as a food resource, bracken fern has been widely used for other purposes such as bedding for animals and man, floor cover, fuel, as an ornamental and ritual plant, as a dying agent, for roofing, baskets, mulch, or as source of potash for the glass and soap industry in various parts of the world in various eras (for further details and literature see Rasmussen 2003). Moreover, in many parts of the world such as Japan, Korea, China or Brazil, bracken is still used for food, since the content of ptaquiloside, which causes bracken toxicity, can be significantly reduced by steeping, boiling, etc. (e.g. Rasmussen 2003).

Furthermore, to find out if bracken could have been a staple food, Ray Mears and Gordon Hillman conducted an experiment concerning digging up the rhizomes of many populations of bracken in several parts of the British Isles. Surprisingly, they failed to find any with sufficient stores of starch to justify the effort expended, which highlights the importance of detailed local knowledge when foraging for wild foods (Mears, Hillman 2007).

Turning now to the archaeological record, one should bear in mind that spores of bracken fern, Pteridium aquilinum, appear in the pollen record in the central European Mesolithic (e.g. Pokorný et al. 2008). Another striking fact about the pollen record is that bracken spores seem to be significantly correlated with human activity and disturbances visible in the pollen record (Pokorný 1999; Kuneš et al. 2008).

The important question that remains to be answered is whether bracken fern was utilized by Mesolithic huntergatherers, as implied by a Western Washington analogy. In this respect, particularly interesting is the case of the Late Mesolithic Netherlands. L. Kubiak Martens (2008) conducted an analysis of charred parenchymal tissue from vegetative parts of plants originating from a large number of samples which are associated with the Late Mesolithic site of Hattemerbroek using scanning electron microscope (SEM). She succeeded in identifying parenchymal tissue of at least two types of fern - bracken (Pteridium aquilinum) and most likely male fern (Dryopteris filix-mas). These were found along with some other plants such as horsetail (Equisetum) or a rhizome belonging to Cyperaceae. According to the author, the context they come from suggests that they represent food waste, but they must have first become charred, likely during cooking beforehand elsewhere.

It is clear at this point that the identification of charred fragments of pyrenchymatical tissue from tubers and rhizomes using SEM is of crucial importance and that evidence gained by this technique is easily overlooked when standard methods of plant identification are used (Perry 1999; Kubiak-Martens 1999; 2008; Mason et al. 2002). However, the identification of root food is not a common part of archaeobotanical research. As already stated, it is obvious that the analysis of roots and tubers is essential in the study of plant use in the Mesolithic as well as the huntergatherer economy. Lastly, it is important to note that the case of bracken fern is only one of many possible plant resources.

\subsection{Other uses}

Apart from the use of plants for food and medicine, other uses such as for dyeing, tanning, constructions, vessels or cordage should also be taken into account. Taxa such as Phragmites australis, Pteridium aquilinum, Typha angustifolia/latifolia, Quercus sp., Cornus sanguinea, Urtica dioica etc. can all be mentioned here.

\section{Evidence from the Czech Republic}

As already noted above, only several Mesolithic sites have been investigated archaeobotanically in the Czech Republic (Figure 1). The evidence comes from two key research areas - the north Bohemian sandstone region and the Třeboň basin in the southern part of the Czech Republic.
Figure 1. Location of sites mentioned in the text projected on a map of the Czech Republic. 1 - Kristova jeskyně, 2 - Jezevčí převis, 3 Okrouhlík, 4 - Dvojitá brána, 5 - Pod zubem 6 - Pod křídlem, 7 - Schwarzenberg Lake. Map created by M. Pták.

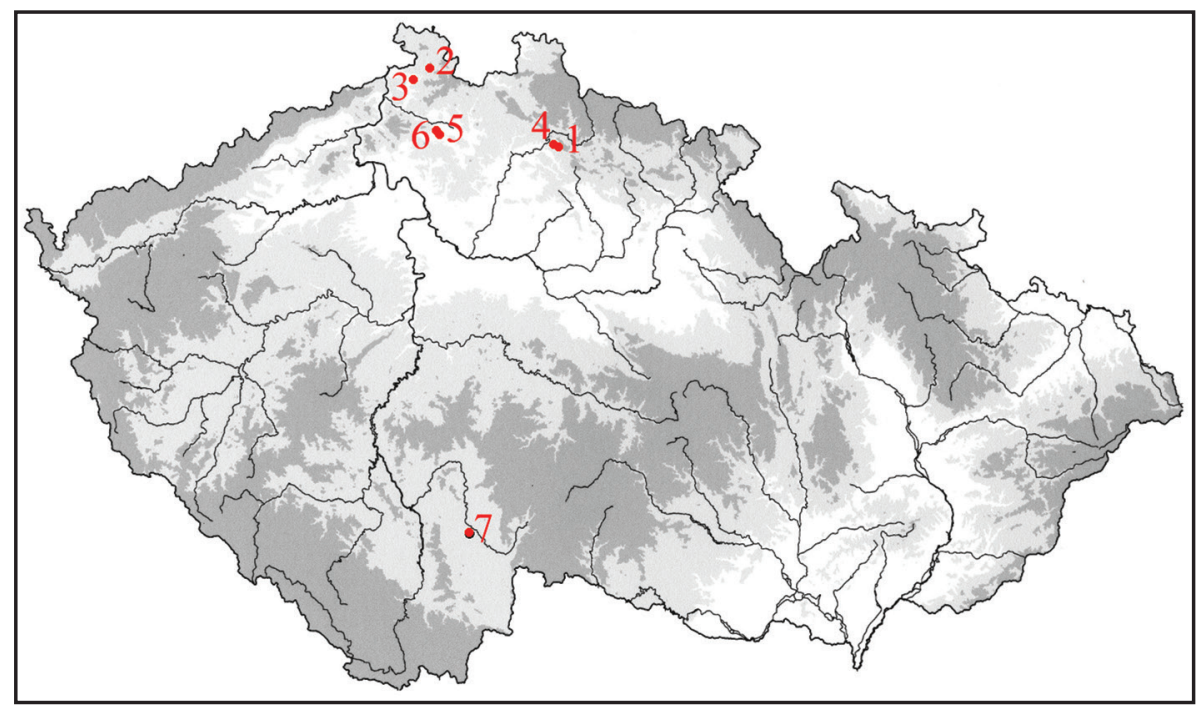




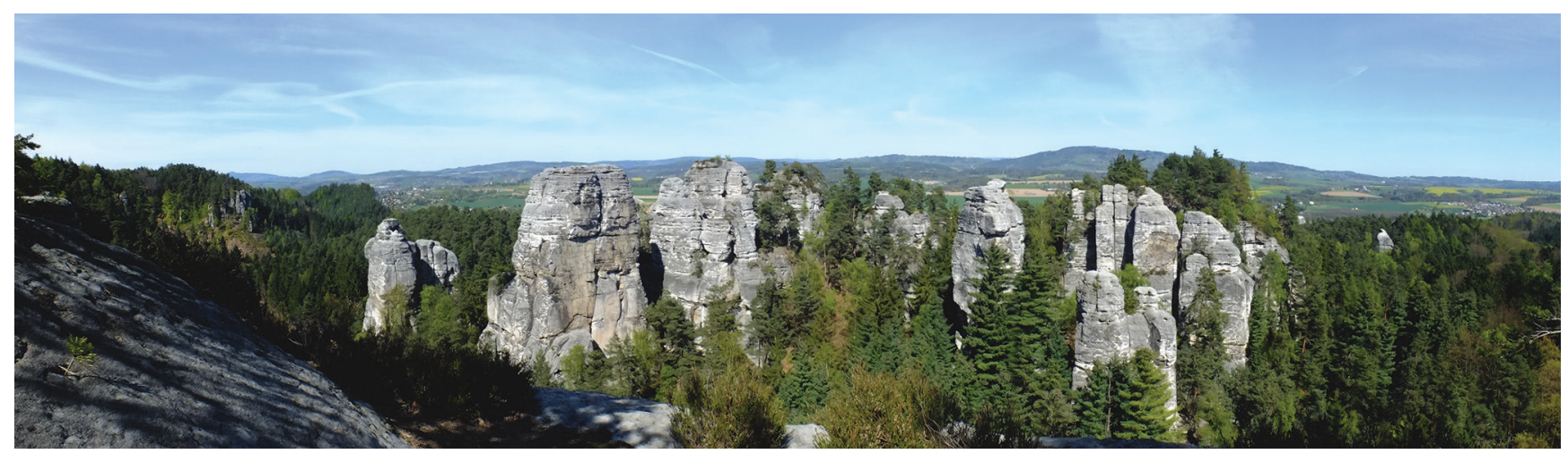

Figure 2. The North Bohemian pseudokarst landscape. Photo: P. Šída.

\subsection{Sandstone rockshelters of northern Bohemia}

The north Bohemian sandstone region (Figure 2) had represented an area without recognized Late Palaeolithic and Mesolithic settlements for a long time, the investigation of the Mesolithic within the region having been neglected in spite of numerous collections of Mesolithic industry obtained before the Second World War, which were mistakenly dated to the Eneolithic due to the research methods of that time. Nevertheless, according to the current state of research, the Mesolithic occupation of the area seems to have been much more intensive (Svoboda 2003; Svoboda et al. 2007; Šída, Prostředník 2007), having implications for various issues of further landscape development.

Turning now to the macroremain evidence, the issue of plant use in the studied area has only been tackled by revealing a number of carbonised hazelnut shells in the Mesolithic layers of several sites (e.g. Arba, Sojčí převis), which were discovered rather accidentally by the naked eye. Since then, another four sites - Kristova jeskyně (Komárková 2005), Jezevčí převis (Pokorný 2003), Okrouhlík (Hajnalová in Svoboda et al. 2007) and Dvojitá brána (Divišová 2014) have been investigated using fine sieving and flotation of the sediment. The carbonised plant macroremains from these sites are associated with the hearths and layers dated to the Mesolithic period and may thus indicate their human manipulation. These comprise the remains of Corylus avellana, Rubus idaeus, Rubus sp., Sambucus nigra, S. racemosa, Chenopodium album and Poaceae.

With respect to functional analyses, some evidence also comes from the sites of Pod zubem and Pod křídlem, where analyses of stone tools including microscopic use-wear and residues analyses were performed - and plant processing as the primary activity at the short-time site Pod krrídlem was suggested. Alternatively, stone tools recovered from the long-term site Pod zubem indicate they were used on a variety of materials. These traces, however, cannot be clearly associated with food preparation (Hardy, Svoboda 2009).

\subsection{Wetlands of the Třebon̆ basin}

The Třeboň basin, specifically the site of Schwarzenberg Lake (Figure 3 ) is one of the best investigated regions in terms of palynology (Pokorný et al. 2010). The site was discovered in the 1970s, when V. Jankovská identified lacustrine sediments under a peat layer in the wetland area adjacent to the presentday fishpond (Jankovská 1980). The uninterrupted sequence of deposited sediments is unique for its potential based on conditions suitable for both palaeoenvrionmental and archaeological research. Therefore, investigations of the lake have brought important data on vegetation, landscape development and human occupation since the end of the Last Glacial Maximum (Pokorný, Jankovská 2000; Pokorný et al. 2008; 2010). A point deserving attention is the finding

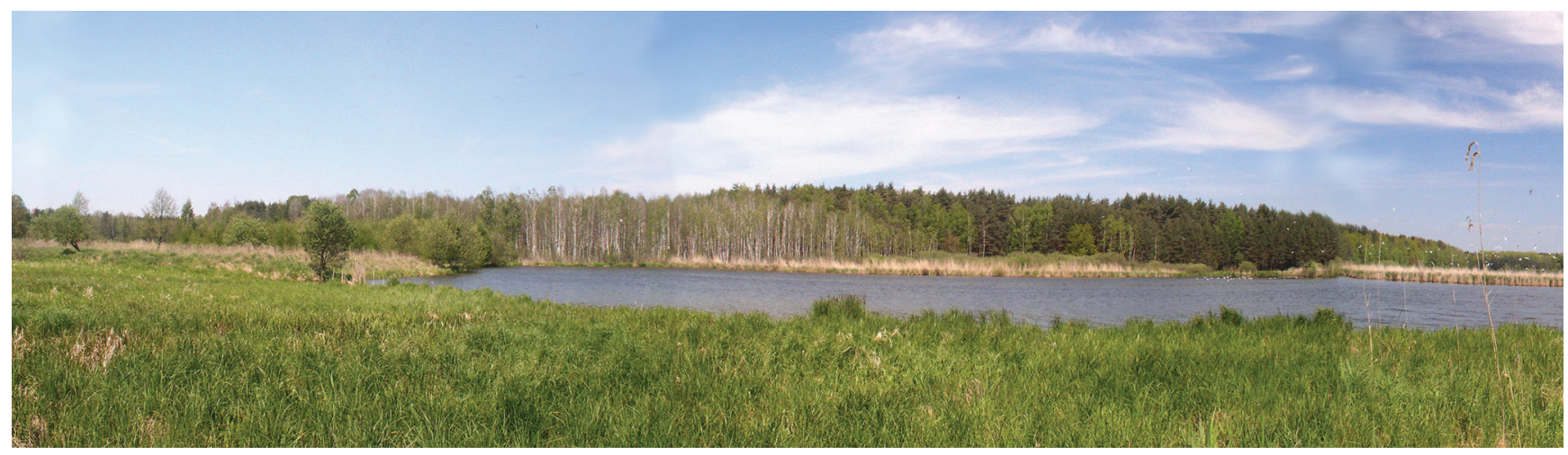

Figure 3. A view of the present landscape in the area of the former Schwarzenberg Lake. Photo: P. Šída. 
of exceptionally intensive settlement in the Early and Middle Holocene periods, which was first discovered indirectly based on the presence of pollen grains of anthropogenic indicators and large quantities of microscopic charcoal particles in lacustrine sediments (Pokorný et al. 2008; 2010).

Mesolithic occupation was confirmed and further studied by means of archaeological excavation, focused on the wet shore of the former lake as well as on dry archaeological situations lying on the sandy peninsula adjacent to the original shore of the lake. Wetland excavation concentrated on the least disturbed southern section of the shore. This excavation fulfilled the potential of wet shore sections and provided the organic strata rich in pollen grains and vegetation remains including large pieces of fresh wood. Also, finds of uncarbonised plant macroremains of Corylus avellana, Rubus idaeus, and Rubus saxatilis within the lake sediments point to a Mesolithic settlement, likely representing gathered foodstuff. Moreover, the finds of Corylus avellana and Trapa natans are dated to the very beginning of the Holocene and could be related to their introduction to the region (Pokorný et al. 2008; 2010). Unfortunately, the dry situations turned out to contain a great amount of contamination from the modern fishpond, reflecting depositional and postdepositional circumstances rather than past human activities (Divišová 2014).

\section{Conclusion}

The archaeobotany of Mesolithic hunter-gatherers represents a seriously understudied research topic. However, some patterns, including woodland clearance or utilisation of selected plant taxa, can be observed. The conclusion that can be drawn at this point is that by the Late Mesolithic, the patterns of plant use support the notion of controlled, regular, and intensive use of plant resources on a scale which left an imprint on the landscape and not just the incidental and opportunistic use of plants for food.

Some methodological implications can be drawn, of which the most important seems to be the identification of parenchymatous issue, since there is growing evidence for the consumption of roots, tubers, bulbs or rhizomes among past, as well as recent, hunter-gatherer communities.

Focusing on the territory of the Czech Republic itself, a few studies that have brought extremely scarce archaeobotanical data in terms of plant remains found in a Mesolithic context have been made. The presence of Corylus avellana, Trapa natans, Rubus idaeus, $R$. saxatilis, Sambucus nigra, $S$. racemosa, Chenopodium album is stressed. However, the issue of their manipulation or even utilisation by humans needs to be studied and should be tested in future research.

Finally, the review strongly reflects the growing need for interdisciplinary work to address the issues related to Mesolithic hunter-gatherers. This is required both from the perspective of the archaeobotany itself, which has to apply a full range of techniques such as pollen, macroremains, wood and charcoal, phytolith, and starch analyses, as well as by means of incorporating various approaches including the reflection of overall archaeological context, analyses of stable isotopes, use-wear analyses, and last, but not least, the integration of ethnobotanical and experimental work, which is also of an crucial importance.

\section{Acknowledgements}

The contribution forms part of the research project "Prior to the Neolithic: Contextual Analysis of Environmental Dynamics during Early Postglacial Transformation of Central Europe", financed by the Czech Science Foundation (13-08169S). The macroremain analysis was supported by GAJU 116/2013/P - Bioarcheologie jižních Čech (20132015). We would like to thank Sabine Karg and Jaromír Beneš for their valuable remarks and overall help. We also greatly appreciate the constructive comments of anonymous reviewer, who significantly helped to improve the manuscript.

\section{References}

AURA, J. E., CARRIÓN, Y., ESTRELLES, E., PERÉZ JORDÀ, G. 2005: Plant economy of hunter-gatherer groups at the end of the last Ice Age: plant macroremains from the cave of Santa Maira (Alacant, Spain) ca. 12000-9000 B.P. Vegetation History and Archaeobotany 14, 542-550.

BÁNFFY, E. 2005: Mesolithic-Neolithic contacts as reflected in ritual finds. Documenta Praehistorica 32, 73-86.

BEHRE, K.-E. 2007: Evidence for Mesolithic agriculture in and around Central Europe? Vegetation History and Archaeobotany 16, 203-219.

BENEŠ, J. 2013: Počátky zemědělství. MS. Habilitation thesis. Deposited: Faculty of Environmental Sciences, Czech University of Life Sceinces Prague, Praha.

BISHOP, R. R., CHURCH, M. J., ROWLEY-CONWY, P. A. 2013: Seeds, fruits and nuts in the Scottish Mesolithic. Proceedings of the Society of Antiquaries of Scotland 143, 9-72.

BISHOP, R. R., CHURCH, M. J., ROWLEY-CONWY, P. A. 2014: Firewood, food and human niche construction: the potential role of Mesolithic hunter-gatherers in actively structuring Scotland's woodlands. Quaternary Science Reviews 108, 51-75.

BOS, J. A. A., URZ, R. 2003: Late glacial and early Holocene environment in the middle Lahn river valley (Hessen, Central-west Germany) and the local impact of early Mesolithic people - pollen and macrofossil evidence. Vegetation History and Archaeobotany 12, 19-36.

BROWN, T. 1997: Clearances and clearings: deforestation in Mesolithic/ Neolithic Britain. Oxford Journal of Archaeology 16, 133-146.

BUROV, G. M. 1998: The use of vegetable materials in the Mesolithic of northeast Europe. In: Zvelebil, M., Dennel, R., Domanska, L. (Eds): Harvesting the sea, farming the forest. Sheffield Archaeological Monographs, Shefield, 53-63.

CLARKE, D. 1976: Mesolithic Europe: the economic basis. In: Sieveking G. de G., Longworth, I. H., Wilson, K. E. (Eds.): Problems in economic and social archaeology, Duckworth, London, 449-481.

CORDAIN, L., MILLER, J. B., EATON, S. B., MANN, N., HOLT, S. H. A., SPETH, J. D. 2000: Plant-animal subsistence ratios and macronutrient energy estimates in worldwide hunter-gatherer diets. American Journal of Clinical Nutrition 71, 682-692.

DANUYNE-PEATY, L. 2001: Human impact on vegetation. In: Brothwell, D. R., Pollard, A. M. (Eds.): Handbook of Archaeological Sciences. Wiley, London, 379-392.

DAVIES, P., ROBB, J. G., LADBROOK, D. 2005: Woodland clearance in the Mesolithic: the social aspects. Antiquity 79, 280-288.

DEFORCE, K., BASTIAENS, J., VAN NEER, W., ERVYNCK, A., LENTACKER, A., SERGANT, J., CROMBÉ, P. 2013: Wood charcoal 
and seeds as indicators for animal husbandry in a wetland site during the late mesolithic-early neolithic transition period (Swifterbant culture, ca. 4600-4000 BC) in NW Belgium. Vegetation History and Archaeobotany 22, 51-60.

DÉNES, A., PAPP, N., BABAI, D., CZÚCZ, B., MOLNÁR, Z. 2012: Wild plants used for food by Hungarian ethnic groups living in the Carpathian Basin. Acta Societatis Botanicorum Poloniae 81, 381-396.

DIETSCH, M. F. 1996: Gathered fruits and cultivated plants at Bercy (Paris), a Neolithic village in a fluvial context. Vegetation History and Archaeobotany 5, 89-97.

DIVIŠOVÁ, M. 2014: Hunter-gatherer archaeobotany: Central European Mesolithic. MS. Master diploma thesis. Deposited: Faculty of Science, University of South Bohemia, České Budějovice.

EVANS, C., POLLARD, J., KNIGHT, M. 1999: Life in woods: three throws, "settlement" and forest cognition. Oxford Journal of Archaeology $18,241-254$

FILIPOVIĆ, D. Z., ALluÉ, E. A., BORIĆ, D. R. 2010: Integrated carpological and anthracological analyses of plant record from the Mesolithic site of Vlasac, Serbia. Journal of the Serbian Archaeological Society 26, 145-161.

FISHER, P., BENDER, A. 1970: The Value of Food. Oxford University Press, Oxford.

GRAY, J. P. 1999: A corrected ethnographic atlas. World Cultures 10, $24-85$.

HARDY, B. L. 2010: Climatic variability and plant food distribution in Pleistocene Europe: Implications for Neanderthal diet and subsistence. Quaternary Science Reviews 29, 662-679.

HARDY, K. 2007: Where would we be without string? Ethnographic and prehistoric evidence for the use, manufacture and role of string in the Upper Palaeolithic and Mesolithic of Northern Europe. In: Beugnier, V., Crombé, P. (Eds.): Plant processing from a prehistoric and ethnographic perspective. BAR International Series 1718. John and Erica Hedges Ltd., Oxford, 9-22.

HARDY, K. 2008: Prehistoric string theory. How twisted fibres helped to shape the world. Antiquity 82, 271-280.

HARDY, B. L., SVOBODA, J. A. 2009: Mesolithic stone tool function and site types in Northern Bohemia, Czech Republic. In: Haslam, M., Robertson, G., Crowther-Smith, A., Nugent, S., Kirkwood, L. (Eds.) Archaeological science under a microscope: studies in residue and ancient DNA analysis in honour of Thomas H. Loy, ANU E Press, Canberra, 159-174.

HATHER, J. G., MASON, S. L. R. 2002: Introduction: some issues in the archaeobotany of hunter-gatherers. In: Hather, J. G., Mason, S. L. R. (Eds.): Hunter-gatherer archaeobotany. Perspectives from the northern temperate zone. University College London, London, 1-14.

HATHER, J. G., MASON, S. L. R. (Eds.) 2002: Hunter-gatherer archaeobotany. Perspectives from the northern temperate zone. University College London, London.

HATHER, J. G. 1991: The identification of charred archaeological remains of vegetative parenchymous tissue. Journal of Archaeological Science $18,661-675$.

HATHER, J. G. 1993: An archaeobotanical guide to root and tuber identification. Volume 1. Europe and South West Asia. Oxbow books, Oxford.

HATHER, J. G. 2000: Archaeological parenchyma. Archetype Publications, London.

HODDER, I. 1990: The domestication of Europe. Blackwell, Oxford.

HOLDEN, T. G., HATHER, J. G., WATSON, J. P. N. 1995: Mesolithic plant exploitation at Roc del Migdia, Catalonia. Journal of Archaeological Science 22, 769-778.

HOLST, D. 2010: Hazelnut economy of early Holocene hunter-gatherers: a case study from Mesolithic Duvensee, northern Germany. Journal of Archaeological Science 37, 2871-2880.

HURCOMBE, L. 2000: Plants as the raw materials for crafts. In: Fairbairn, A. S. (Ed.): Plants in Neolithic Britain and beyond. Oxbow, Oxford, $155-173$

HURCOMBE, L. 2007: Plant processing for cordage and textiles using serrated flint edges: new chaînes operatoires suggested by combining ethnographic, archaeological and experimental evidence for bast fibre processing. In: Beugnier, V., Crombé, P. (Eds.): Plant processing from a prehistoric and ethnographic perspective. BAR International Series 1718. John and Erica Hedges Ltd., Oxford, 41-66.
INNES, J. B., BLACKFORD, J. J., DAVEY, P. J. 2003: Dating the introduction of cereal cultivation to the British Isles. Early palaeoecological evidence from the Isle of Man. Journal of Quaternary Science 18, 603-613.

JACOBI, R. M., TALLIS, J. M., MELLARS, P. 1976: The south Pennine Mesolithic and the ecological record. Journal of Archaeological Science 3, 307-320.

JACOMET, S., KREUZ, A. 1999: Archäobotanik. Aufgaben, Methoden und Ergebnisse vegetations- und agrargeschichtlicher Forschungen. Ulmer, Stuttgart.

JANKOVSKÁ, V. 1980: Paläobotanische Rekonstruktion der Vegetationsentwicklung im Becken Třeboňská pánev während des Spätglazials und Holozäns. Vegetace ČSSR A11. Academia, Praha.

JENIKE, M. R. 2001: Nutritional ecology: diet, physical activity and body size. In: Panter-Brick, C., Layton, R. H., Rowley-Conwy, P. (Eds.): Hunter-gatherers. An interdisciplinary perspective. Cambridge University Press, Cambridge, 205-238.

JOCHIM, M. 1976: Hunter-gatherer subsistence and settlement. Academic Press, London.

KARG, S. 2006: The water chestnut (Trapa natans L.) as a food resource during the 4th to 1st millennia BC at Lake Federsee, Bad Buchau (southern Germany). Environmental Archaeology 11, 125-130.

KELLY, R. L. 1995: The foraging spectrum: diversity in hunter-gatherer lifeways. Smithsonian Institution Press, Washington, D.C.

KLASSEN, L. 2004: Jade und Kupfer: Untersuchungen zum Neolithisierungsprozess im westlicheno Ostseeraum unter besonderer Berücksichtigung der Kulturentwicklung Europas 5500-3500 BC. Jutland Archaeological Society publications 47. Aarhus University Press, Aarhus.

KLIMENKO, S. 2004: The Cornelian cherry (Cornus mas L.): collection, preservation, and utilization of genetic resources. Journal of Fruit and Ornamental Plant Research 12, 93-98.

KNÖRZER, K.-H., GERLACH, R., MEURERS-BALKE, J., KALIS, A. J., TEGTMEIER, U., BECKER, W. D., JÜRGENS, A. 1999: PflanzenSpuren. Archäobotanik im Rheinland. Agrarlandschaft und Nutzpflanzen in Wandel der Zeiten. Rheinland-Verlag, Köln.

KOMÁRKOVÁ, V. 2005: A report on plant macroremains from Kristova jeskyně. MS. Deposited: Laboratory of Archaeobotany and Palaeoecology, Faculty of Science, České Budějovice.

KUBIAK-MARTENS, L. 1996: Evidence for possible use of plant foods in Palaeolithic and Mesolithic diet from the site of Całowanie in the central part of the Polish Plain. Vegetation History and Archaeobotany 5, 33-38.

KUBIAK-MARTENS, L. 1999: The plant food component of the diet at the Late Mesolithic (Ertebølle) settlement at Tybrind Vig, Denmark. Vegetation History and Archaeobotany 8, 117-127.

KUBIAK-MARTENS, L. 2002: New evidence for the use of root foods in pre-agrarian subsistence recovered from the late Mesolithic site at Halsskov, Denmark. Vegetation History and Archaeobotany 11, 23-31.

KUBIAK-MARTENS, L. 2008: Voedseleconomie: parenchym en andere plantaardige macroresten (Hanzelijn Oude Land - Knooppunt Hattemerbroek). BIAXiaal 386.

KUNEŠ, P., POKORNÝ, P., ŠÍDA, P. 2008: Detection of the impact of early Holocene hunter-gatherers on vegetation in the Czech Republic, using multivariate analysis of pollen data. Vegetation History and Archaeobotany 17, 269-287.

LEE, R. B. 1968: What hunters do for a living, or, how to make out on scarce resources. In: Lee, R. B., DeVore, I. (Eds.): Man the hunter. Aldine, Chicago, 30-48.

LEE, R. B. 1973: Mongongo: the ethnography of a major wild food resource. Ecology of Food and Nutrition 2, 307-321.

LOSEY, R. J., STENHOLM, N., WHEREAT-PHILLIPS, P., VALLIANATOS, H. 2003: Exploring the use of red elderberry (Sambucus racemosa) fruit on the southern Northwest Coast of North America. Journal of Archaeological Science 30, 695-707.

ŁUCZAJ, Ł. 2012: Ethnobotanical review of wild edible plants of Slovakia. Acta Societatis Botanicorum Poloniae 81, 271-281.

MARINOVA, E., FILIPOVIC, D., OBRADOVIĆ, D., ALLUÉ, E. 2013: Wild plant resources and land use in the Mesolithic and early Neolithic south-east Europe: Archaeobotanical evidence from the Danube catchment of Bulgaria and Serbia. Offa 69.

MASON, S. L. R., HATHER, J. G., HILlMAN, G. C. 2002: The archaeobotany of European huter-gatherers: some preliminary 
investigations. In: Hather, J. G., Mason, S. L. R. (Eds.): Huntergatherer archaeobotany. Perspectives from the northern temperate zone. University College London, London, 188-196.

MASON, S. L. R., HATHER, J. G. 2000: Parenchymatous plant remains. In: Mithen, S. (Ed.): Hunter-Gatherer Landscape Archaeology: The Southern Hebrides Mesolithic Project 1988-1998. Volume 2. McDonald Institute, Cambridge, 415-425.

MASON, S. R. L. 2000: Fire and Mesolithic subsistence - managing oaks for acorns in northwest Europe? Palaeogeography, Palaeoclimatology, Palaeoecology 164, 139-150.

MCGLONE, M. S., WILMSHURST, J. M., LEACH, H. M. 2005: An ecological and historical review of bracken (Pteridium esculentum) in New Zealand, and its cultural significance. New Zealand Journal of Ecology 29, 165-184.

MEARS, R., HILLMAN, G. C. 2007: Wild foods. Hodder \& Stoughton, London.

MELLARS, P. 1976: Fire ecology, animal populations and man: a study of some ecological relationships in prehistory. Proceedings of the Prehistoric Society 42, 15-45.

MITHEN, S., FINLAY, N., CARRUTHERS, W., CARTER, S., ASHMORE P. 2001: Plant Use in the Mesolithic: Evidence from Staosnaig, Isle of Colonsay, Scotland. Journal of Archaeological Science 28, 223-234.

MITHEN, S. 1996: The prehistory of the mind. A search for the origins of art, religion and science. Thames and Hudson, London.

MOERMAN, D. E. 1998: Native American Ethnobotany. Timber Press, Portland Oregon.

MOORE, J. 2003: Enculturation through fire: beyond hazelnuts and into the forest. In: Larson, L., Kindgren, H., Knutsson, K., Loeffler, Åkerlund, D (Eds.): Mesolithic on the move. Papers presented at the sixth international conference on the Mesolithic in Europe, Stockholm 2000. Oxbow books, Oxford, 139-144.

MURDOCK, G. P. 1967: Ethnographic atlas. University of Pittsburgh Press, Pittsburgh.

NORTON, H. H. 1979: Evidence for bracken fern as a food for aboriginal peoples of Western Washington. Economic Botany 33, 384-396.

NOVÁKOVÁ, K., NOVÁK, J., ŠAFRÁNKOVÁ, J. 2008: Paleoekologický výzkum Velanské cesty u Českých Velenic: zachycení lidské činnosti. In: Beneš, J., Pokorný, P. (Eds.): Bioarcheologie v České republice. University of South Bohemia - Institute of Archaeology of the Academy of Sciences of the Czech Republic, České Budějovice - Praha 99-114.

OPRAVIL, E. 2003: Rostlinné makrozbytky. In: Svoboda, J. (Ed.): Mezolit severnich Čech. Komplexni výzkum skalnich převisů na Českolipsku a Déćinsku, 1978-2003. Institute of Archaeology of the Academy of Sciences of the Czech Republic, Brno, 38-42.

OUT, W. A., VERHOEVEN, K. 2014: Late Mesolithic and Early Neolithic human impact at Dutch wetland sites: the case study of HardinxveldGiessendam De Bruin. Vegetation History and Archaeobotany 23, 41-56.

OUT, W. A. 2008a: Gathered food plants at Dutch Mesolithic and Neolithic wetland sites. In: Baker, S., Allen, M., Middle, M., Poole, K. (Eds.): Food and drink in archaeology I. Prospect Books, Nottingham, 84-95.

OUT, W. A. 2008b: Selective use of Cornus sanguinea L. (red dogwood) for Neolithic fish traps in the Netherlands. Environmental Archaeology $13,1-10$.

OUT, W. A. 2009: Sowing the seed? Human impact and plant subsistence in Dutch wetlands during the Late Mesolithic and Early and Middle Neolithic (5500-3400 cal BC). Leiden University Press, Leiden.

OUT, W. A. 2012: What's in a hearth? Seeds and fruits from the Neolithic fishing and fowling camp at Bergschenhoek, The Netherlands, in a wider context. Vegetation History and Archaeobotany 21, 201-214.

PANTER-BRICK, C., LAYTON, R. H., ROWLEY-CONWY, P. 2001: Lines of enquiry. In: Panter-Brick, C., Layton, R. H., Rowley-Conwy, P. (Eds.): Hunter-gatherers. An interdisciplinary perspective. Cambridge University Press, Cambridge, 1-11.

PERRY, D. 1999: Vegetative tissues from Mesolithic sites in the Northern Netherlands. Current Anthropology 40, 231-237.

PERRY, D. 2002: Preliminary results of an archaeobotanical analysis of Mesolithic sites in the Veenkoloniën, Province of Groningen, the Netherlands. In: Hather, J. G., Mason, S. L. R. (Eds.): Hunter-gatherer archaeobotany. Perspectives from the northern temperate zone. University College London, London, 108-116.

POHL, R. W. 1955: Toxicity of ferns and equisetum. American Fern
Journal 45, 95-97.

POKORNÝ, P. 1999: Vliv mezolitických populací na krajinu a vegetaci: nové nálezy ze staršího holocénu Třeboňské pánve. Zprávy ČAS 38, 21-22.

POKORNÝ, P. 2003: Rostlinné makrozbytky. In: Svoboda, J. (Ed.): Mezolit severních Čech. Komplexní výzkum skalních previsů na Českolipsku a Déčinsku, 1978-2003. Institute of Archaeology of the Academy of Sciences of the Czech Republic, Brno, 272-273.

POKORNÝ, P., JANKOVSKÁ, V. 2000: Long-term vegetation dynamics and the infilling process of a former lake (Švarcenberk, Czech Republic). Folia Geobotanica 35, 433-457.

POKORNÝ, P., SÁDLO, J. 2008: Kolapsy v českém pravěku. In: Bárta, M., Pokorný, P. (Eds.): Něco překrásného se konči. Dokořán, Praha, 89-105. POKORNÝ, P., ŠÍDA, P., CHVOJKA, O., ŽÁČKOVÁ, P., KUNEŠ, P., SVĚTLÍK, I., VESELÝ, J. 2010: Palaeoenvironmental research of the Schwarzenberg Lake, southern Bohemia, and exploratory excavations of this key Mesolithic archaeological area. Památky archeologické 101, 5-38.

POKORNÝ, P., ŠÍDA, P., KUNEŠ, P, CHVOJKA, O. 2008: Mezolitické osídlení bývalého jezera Švarcenberk (jižní Čechy) v kontextu vývoje př́rodního prostředí. In: Beneš, J., Pokorný, P. (Eds.): Bioarcheologie v České republice. University of South Bohemia - Institute of Archaeology of the Academy of Sciences of the Czech Republic, České Budějovice Praha, 145-176.

POSKA, A., SAARSE, L. 2006: New evidence of possible crop introduction to north-eastern Europe during the Stone Age. Cerealia pollen finds in connection with the Akali Neolithic settlement, East Estonia. Vegetation History and Archaeobotany 15, 169-179.

PRICE, D. 1978: The Mesolithic of western Europe. Journal of World Prehistory 1, 225-305.

RASMUSSEN, L. R. 2003: Ptaquiloside - an environmental hazard? The Royal Veterinary and Agricultural University of Denmark, Frederiksberg.

REGNELL, M., GAILLARD, M.-J., BARTHOLIN, T. S., KARSTEN, P. 1995: Reconstruction of environment and history of plant use during the Late Mesolithic (Ertebølle culture) at the inland settlement of Bökeberg III, southern Sweden. Vegetation History and Archaeobotany 4, 67-91.

REGNELL, M. 2012: Plant subsistence and environment at the Mesolithic site Tågerup, southern Sweden: new insights on the "Nut Age". Vegetation History and Archaeobotany 21, 1-16.

RENFREW, C. 1973: Palaeoethnobotany. The prehistoric food plants of the Near East and Europe. Columbia University Press, New York.

ROBINSON, D. E., HARILD, J. A. 2002: Archaeobotany of an early Ertebølle (Late Mesolithic) site at Halsskov, Zealand, Denmark. In: Hather, J. G., Mason, S. L. R. (Eds.): Hunter-gatherer archaeobotany. Perspectives from the northern temperate zone. University College London, London, 84-95.

ROBINSON, M. A. 2000: Further considerations of Neolithic charred cereals, fruits and nuts. In: Fairbairn, A. S. (Ed.): Plants in Neolithic Britain and beyond,. Neolithic Studies Group Seminar Papers 5. Oxbow Books, Oxford, 85-90.

RÖSCH, M. 2000: Pflanzenreste. In: Kieselbach, C.-J., Kind, J., Miller, A. M., Richter, D. (Eds.): Siebenlinden 2. Ein mesolithischer Fundplatz bei Rottenburg am Neckar, Kreis Tübingen. Materialhefte zur Archaologie in Baden-Württemberg 51. Konrad Theiss, Stuttgart, 59-63.

ROSENBERG, D. 2008: The possible use of acorns in past economies of the Southern Levant: A staple food or a negligible food source? Levant 40, 167-175.

RYMER, L. 1976: The history and ethnobotany of bracken. Botanical Journal of the Linnean Society 73, 151-176.

SÁDLO, J., POKORNÝ, P., HÁJEK, P., DRESLEROVÁ, D., CÍLEK, V. 2008: Krajina a revoluce. Významné přlomy ve vývoji kulturni krajiny českých zemí. Malá skála, Praha.

SIMMONS, I. G. 1996: The environmental impact of later Mesolithic cultures. The creation of Moorland landscape in England and Wales. Edinburgh University Press, Edinburgh.

SIMMONS, I. G., INNES, J. B. 1987: Mid-holocene adaptations and later Mesolithic forest disturbance in Northern England. Journal of Archaeological Science 14, 385-394.

SPETH, J. D., WIDDOWSON, E. M., OFTEDAL, O. T., FOLEY, R. A., VAN SOEST, P. 1991: Protein selection and avoidance strategies of 
contemporary and ancestral foragers: unresolved issues. Philosophical Transactions of the Royal Society of London B34, 265-270.

SVOBODA, J. A., HAJNALOVÁ, M., HORÁČEK, I., NOVÁK, M., PŘICHYSTAL, A., ŠAJNEROVÁ, A., YAROSHEVICH, A. 2007: Mesolithic settlement and activities in rockshelters of the Kamenice river canyon, Czech Republic. Eurasian Prehistory 5, 95-127.

SVOBODA, J. A., NOVÁK, J., NOVÁK, M., SÁZELOVÁ, S., DEMEK, J., HLADILOVÁ, Š., PEŠA, V. 2013: Palaeolithic/Mesolithic stratigraphic sequences at Údolí samoty and Janova zátoka rock shelters (Northern Bohemia). Archäologisches Korrespondenzblatt 43, 469-707.

TILLEY, C. 1994: A phenomenology of landscape. Places, paths and monuments. Berg Publishers, Oxford.

TINNER, W., NIELSEN, E. H., LOTTER, A. F. 2007: Mesolithic agriculture in Switzerland? A critical review of the evidence. Quaternary Science Reviews 26, 1416-1431.

TRINGHAM, R. 2000: Southeastern Europe in the transition to agriculture in Europe: bridge, buffer or mosaic. In: Price, T. D. (Ed.): Europe's first farmers. Cambridge University Press, Cambridge, 19-56.

VERA, F. W. M. 2000: Grazing ecology and forest history. CABI
Publishing, Wallingford.

WARREN, G. 2003: Life in the trees: Mesolithic people and the woods of Ireland. Archaeology Ireland 17, 20-23.

WOOD, J. 2011: Daily practices of prehistoric Europe during the Mesolithic/Neolithic transition. In: Gheorghiu, D. (Ed.): Experiments with past materialities, BAR International Series 2302. Hadrian Books, Oxford, 9-17.

ŽÁČKOVÁ, P. 2008: Rekonstrukce paleoekologických poměrů při zazemňování jezer metodou analýzy rostlinných makrozbytků. MS. Master diploma thesis. Deposited: Faculty of Science, Charles University in Prague, Praha.

ZAPATA, L., CAVA, A., IRIARTE, M. J., BARAYBAR, J. P., DE LA RUA, C. 2002: Mesolithic plant use in the western Pyrenees: implications for vegetation change, use of wood and human diet. In: Hather, J. G., Mason, S. L. R. (Eds.): Hunter-gatherer archaeobotany. Perspectives from the northern temperate zone. University College London, London, 96-107. ZVELEBIL, M. 1994: Plant use in the Mesolithic and its role in the transition to farming. Proceedings of the Prehistoric Society 60, 35-74. 